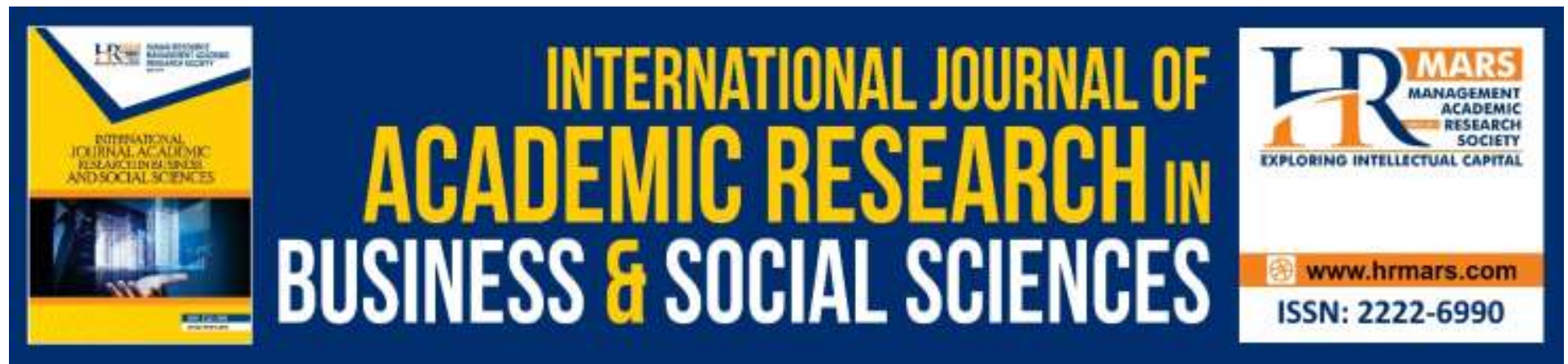

\title{
Learning Leading of the Aborigine Pupils: Comparative Perceptions between Principals and Teachers in Primary Schools Malaysia
}

Hamidah Yusof, Norasibah Abdul Jalil, Mohd Asri Mohd Noor, Marinah Awang

To Link this Article: http://dx.doi.org/10.6007/IJARBSS/v9-i11/6653

DOI: 10.6007/IJARBSS/v9-i11/6653

Received: 17 September 2019, Revised: 23 October 2019, Accepted: 05 November 2019

Published Online: 25 November 2019

In-Text Citation: (Yusof, Jalil, Noor, \& Awang, 2019)

To Cite this Article: Yusof, H., Jalil, N. A., Noor, M. A. M., \& Awang, M. (2019). Learning Leading of the Aborigine Pupils: Comparative Perceptions between Principals and Teachers in Primary Schools Malaysia. International Journal of Academic Research in Business and Social Sciences, 9(11), 1244-1260.

Copyright: (C) 2019 The Author(s)

Published by Human Resource Management Academic Research Society (www.hrmars.com)

This article is published under the Creative Commons Attribution (CC BY 4.0) license. Anyone may reproduce, distribute, translate and create derivative works of this article (for both commercial and non-commercial purposes), subject to full attribution to the original publication and authors. The full terms of this license may be seen

at: http://creativecommons.org/licences/by/4.0/legalcode

Vol. 9, No. 11, 2019, Pg. 1244 - 1260

http://hrmars.com/index.php/pages/detail/IJARBSS

JOURNAL HOMEPAGE

Full Terms \& Conditions of access and use can be found at http://hrmars.com/index.php/pages/detail/publication-ethics 


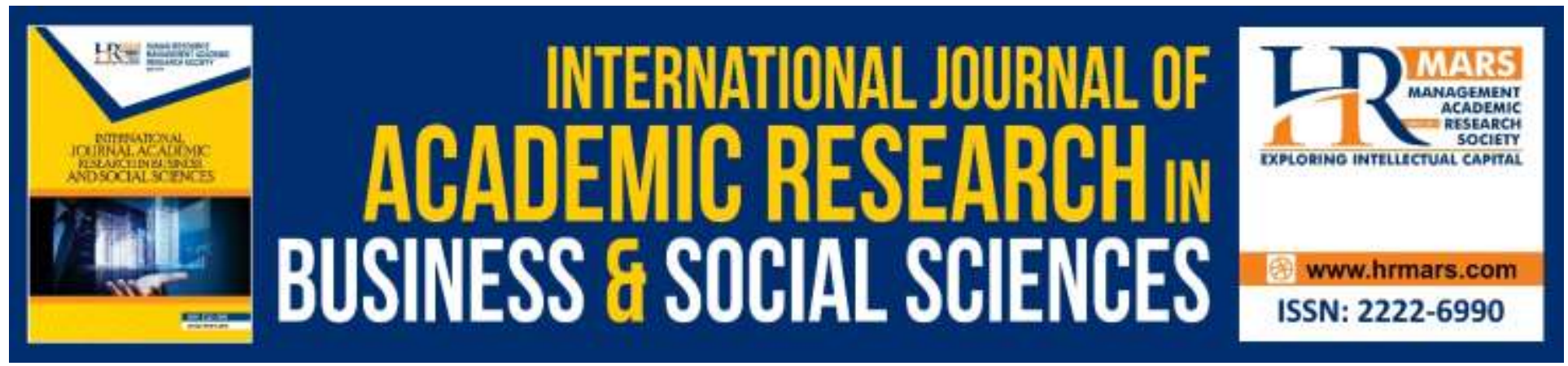

\title{
Learning Leading of the Aborigine Pupils: Comparative Perceptions between Principals and Teachers in Primary Schools Malaysia
}

\author{
Hamidah Yusof, Norasibah Abdul Jalil, Mohd Asri Mohd Noor, \\ Marinah Awang
}

Faculty of Management and Economics, Universiti Pendidikan Sultan Idris

Email: hamidah.yusof@fpe.upsi.edu.my,norasibah@fpe.upsi.edu.my, mohd.asri@fpe.upsi.edu.my,marinah@fpe.upsi.edu.my

\begin{abstract}
The purpose of this study is to compare the principals' and the teachers' perception of aborigine's pupils leading learning factors. The leading learning factors include school climate, principals' role, teacher leadership, teacher behaviour, student motivation, and parental commitment. This study provides an overview of the factors that need to be taken into consideration by principals, teachers, and policymakers to better plan and make decisions for the betterment of aborigine's pupils. A total of nine principals and 113 teachers from nine aborigines primary schools participated in this study. Data were collected using questionnaires and analysed using descriptive statistics. The findings documented that the principals' mean score levels relatively higher than the teachers' score. There was no difference in the priority factor based on the mean score values between the principals and the teacher. The respondents agree that the role of the principals is most important, followed by the school climate, teacher leadership, student motivation, teacher behaviour, and ultimately, parental commitment. This study also discusses the implications and suggestions for improving the role of the leading learning factor of aborigine's pupils.
\end{abstract}

Keywords: School Climate, Principals' Role, Teacher Leadership, Aborigines' Pupils

\section{Introduction}

The government provides various programs to help the aborigines people to move forward in line with the country's progress. However, the impact is still low and need a tremendous leap so that the community is not left behind. One of the primary missions of the government is to change these communities quality of life by ensuring that all these children go through the 
teaching and learning process successfully, and mastered all the needed skills. In Malaysia, education still considered as a mechanism to increase social mobility, especially for the aborigine's people to enter mainstream life. There are four learning leading factors in education, which are students, teachers, principals and parents. These four factors will create a benchmark that can be used by the government to provide initiatives to improve the education system for aborigines' communities. These factors have gained the attention of many researchers. However, there are not many studies that focus on these four factors at once. The study by Ahmad (2013) focused only on the role of the principals; Norsita and Zainal's (2012) study focused on teacher behaviour; Hendri's (2012) study focused on student motivation; Azizi and Mohamad (2010) focus on parental commitment.

Findings and recommendations from previous studies have assisted the government in providing several initiatives (UNICEF, 2011; SUHAKAM, 2010; Kamarulzaman \& Osman, 2008; Mahmud, Amat \& Yaacob, 2008; Nicholas, 2006). However, the study of Sharifah, Samsilah, Aminuddin, Kamaruddin, Mohamad, and Jaimah (2011) acclaimed that there is still a gap in the achievement of the aborigine's students' in education. It is due to an ineffective way of learning; or gain less support from teachers, principals, and parents. A recent study by Norwaliza, Ramlee and Abdul (2016) found that the low achievement of these pupils resulted from the weak role of administrators to apply proactive leadership, inadequate assessment for teachers and lack of available facilities.

The most common problems faced by these aborigines' students are the lack of academic excellence (Kamarulzaman \& Osman, 2008) and the neglection of their existence (Tarmiji, Fujimaki \& Norhashimah, 2013). These have left them marginalised, humiliated, and made them feel inferior. There are also some of the teachers who attended other matters within the teaching hours. The other contributing factors are teaching methods, lack of exciting teaching materials, the class was handover to new teachers and teachers who only teach to pass the public examinations. Moreover, the placement of uncommitted principals and teachers are a major contributing factor. Parents also parted of these factors due to the lack of motivational support for their children and had caused them to drop out. According to the Malaysia Education Blueprint (2013-2025), a various program designed to decrease these total students dropout from formal education. It is including an introduction to Basic Vocational Education, career program counselling conducted by the Psychology and Counselling Division (BPsK), Programme for the parents of Orang Asli and Indigenous students (KEDAP), programme for the Orang Asli and Indigenous Community Students (PIKAP) and the introduction of remodelling kit for curriculum transformation in Orang Asli and Indigenous students. However, the total drop out had increased from 17\% in the previous year to 26\% in 2017 (Ministry of Education, 2018). This result showed that aborigine's community still not appreciated the educational opportunities given to them. As a result, only a small number of these aborigines' students successfully pursuing their studies to higher educational institutions. 
Tarmiji, Fujimaki and Norhashimah (2013) who conducted a study on this subject matter concluded that the hostile attitude of the aborigines towards education and learning had clearly shown that they have failed to accept development because it does not fit with their current lifestyle. They still tied to the traditional way of life. The cultural structure of the family, community and daily living status quo are among the identified factors that contributed to the dropout and the low achievement among these students. They still strongly behold to the spirit of life that strongly connected to nature. Pupils and the learning process are complex issues that influenced by many factors. The previous study had limited these leading learning factors only on school climate factors, the role of principals, teacher leadership, student motivation, teacher behaviour, and parental commitment. Therefore, a detailed study should be carried out to identify the leading learning factors for these aborigines' pupils in the context of their environment. The study of the role of the principals, teachers, students and parents should also be carried out in supporting and leading student learning.

\section{School Climate}

Conducive school climate is an essential component in influencing school's effectiveness and success. School climate defined as a belief, values, and attitudes that build interaction between students, teachers and administrators. It is the result of social interactions between students and teachers that are influenced by the values of education and social services; it also affects student academic achievement and performance (Koth, Bardshaw \& Leaf, 2008). Centre for Curriculum Development (1981) defines it as a school environment that has a productive, comfortable environment that positively influenced the teaching process. According to Hoy and Miskel (2008), a healthy school is a school with a good vibe of environment that can be adaptable in the long run and be able to flourish. This environment will ensure that the external pressure was well managed and the schools' objectives can be understood easily. Besides, conflicts will be resolved quickly if a school environment is healthy.

Payne and Pugh (in Muhamad et al., 2016) introduced five elements of the climate model, which is organisational context, organisational structure, organisational climate, individual and individual environment. In this model, the organisational structure and organisational climate influenced each other. A healthy organisational climate can affect personality, desire, ability, satisfaction, goals, and achievement. Halpin and Croft (1963) stated that school climate is a reflection of one's personality and how it strives to reach the school's climate. In this study, the school climate that led to excellent learning defined as the attitude or behaviour of the principals, teachers, and students as well as the safe and conducive school environment. This study covers social, psychosocial, and the school environment itself.

The excellence of the student is the main goal for every educational institution. Therefore, schools have to plan and implements various activities and programs to achieve this goal. The fun and the conducive environment will ensure students to be more successful, capable of facing multiple challenges in their life and live happily. There are two main sub-ecosystems in a 
students' learning ecosystem. The first one is the school ecosystem, which consisted of the principals, teachers and peers. Another one is the family ecosystem, which included parents and communities that play a direct role in leading student learning. According to Cibulka et al. (2003), there are three main ways on how schools can play a leading role in students learning; (i) teachers need to know each student's learning style to improve students understanding and their capabilities in a natural learning environment; (ii) teachers need to take into account students experiences to clearly execute the knowledge transfer, and (iii) to enhance the students learning more than their existing learning capabilities.

Szabo and Lambert (2002) made the following proclamation; (i) learning is a non-passive active process; (ii) social learning, occurs when students exchange ideas, questions and solve common problems; (iii) students need learning to ensure a meaningful new knowledge and gives this new knowledge means based on individual experiences and sharing; (iv) reflection and meta-cognition contribute to the construction of knowledge and meaning, and ( $v$ ) new knowledge is influenced by past experiences, values and beliefs.

According to the study of Misnah, Hamidah and Marinah (2015), educational leaders rely on individual competencies to; (i) initiate learning: how the students begin the learning process and seek help to start learning; (ii) support learning: how students provide means to continue learning; (iii) customize learning: how students adjust, adapt, purify, take into account the old and new differences, learning for life or lifelong learning and; (iv) generate living: how students develop the ability to make needed decisions.

School safety is also an essential factor in ensuring a secure school environment. It does not only enhance the efficiency of the teaching and learning process but also creating a conducive school climate. According to Wan (2014), under controlled school security, students will feel safe and had no worries to be present at school. They will enjoy a conducive, safe, secure, and peaceful learning environment. Meanwhile, unsafe school conditions will cause fear and worry for the students to be present in the school. Thus, it will make them lost focus on the teaching and learning process.

The fun and cheerful atmosphere at the school and in the classroom will stimulate students' desire to continue learning willingly. Students will be more focused and continue to be actively involved in every program and activity organised by the school. The school's fun atmosphere that emphasis on cleanliness, greenery of the park and appropriate decorations may inspire students positively. The words of encouragement and wisdom found in the school environment may positively motivate the students, to remain to persevere in the pursuit of knowledge (Wan, 2014).

Individual learning is another factor that contributes to the school's success (Scholtes, 2005). The success of the learning process in pupils involves many factors including social background, family background, personality, age, gender and location. Therefore, it is necessary to find the 
appropriate variables that suit well with students' and their local environments. Thus, the role of the school which encompasses the school environment, the principals and the teachers are essential in supporting the learning behaviour of the pupils.

\section{The Function of the Principal}

DeBevoise (1984) states that instructional leadership is the key to the success of the school. Leaders who practice this kind of leadership will contribute more to school effectiveness (Southworth, 2002; Hallinger \& Murphy, 1985). According to NorFoniza and Mohd (2013), leaders have the responsibility, power, and authority, to lead the staff in achieving their vision and mission. They also play an essential role in improving teachers' knowledge and skills by planning and developing strategies. Ishak (2006) have concluded that school principals are critical factors that contribute to school development and progress. They hold responsibilities to monitor teachers teaching quality, student achievement, and, most importantly, school effectiveness. According to Waters, Marzano, and McNulty (2003), in their 30 years of meta-analysis study, leaders (principals) play a crucial role in improving academic achievement. This result aligned with the study of Hamidah and Norasibah (2011) using TIMSS 2003 data that indicate leaders who pay attention to instructional leadership will make a massive impact on student achievement. Sergiovanni (1987) emphasised that the five primary roles played by principals at school are technical leaders, human leaders, educational leaders, symbolic leaders, and cultural leaders.

In Malaysia, instructional leadership begins to get the attention of principals when schools are showing improvement in academic achievement. According to a study conducted by Boon (2005), it is an improvement strategy to enhance students' academic success. Principals who practice instructional leadership style will always show their interaction with students' performance. They will still communicate with students to understand their learning technique. Then, they will use it to plan for better learning strategies in the future. In conclusion, school leaders are the most important person in an organisation as they are the head of all administrative matters. A leader's ability in the administration of the school can determine whether the school has an excellent or poor academic performance.

\section{Teacher Leadership and Teacher Attitude}

The main leader in students learning factor is the teacher. Teachers act as learning leaders in students daily learning activities. Therefore, teachers need to continually assess their teaching skills to ensure that the methods used can fulfil the needs of the students (MacBeath, 2005). They need to be more creative in understanding students' potential, be a good mentor and play a significant role in increasing student dignity and self-esteem to make learning more meaningful (Abdullah et al., 2011; Ragbir, 2010; Salhah \& Ainon, 2007). Moreover, teachers who are responsible for teaching these aborigines pupils need to be more patient with the challenges of the school's location. Most of these schools located in a very remote area. Therefore, these teachers not only need to inspire the students but also themselves. 
Some of the factors that influence teacher leadership are teacher's values, culture, skills, climate, and knowledge. Moral aspects that incorporate values, principles, and ethics enable teachers to act in a better way, whether they observed by other people or not (Sergiovanni, 1992, 1987). The aspects of skills and knowledge are also crucial in determining teacher leadership. The seven features of an effective teacher leadership suggested by Shippen and Shippen (2004) are; have a clear classroom vision to guide students to excellence; have a flexible, thoughtful and openminded attitude; being an example to his disciples; wisely create a sense of belonging among students and their organisation; not being selfish; making fair, honest and humble judgment toward students; and practice a lifelong learning. According to Moskal and Bath (2001), teachers are leaders who will bring change to students and the classroom. The role of the teachers is not just as a leader to the students, but also as facilitators, managers, and inventors for students. Therefore, to succeed in this diversity, leadership elements such as values, norms, attitudes, knowledge, and skills are essential to teachers. Without these leadership elements, teachers will not be able to excel in their job.

Norreza (2011) in her study figured that teacher leadership is not limited in the classroom context only that explicitly referring to teachers interacting with students, but teacher leadership also covers teacher's ability to communicate and collaborate well with administrators and peers to improve the process and outcomes of students' learning. It is the process of influencing colleagues and students to enhance academic performances and school success. In fostering a good school culture, a teacher should be equipped with a variety of leadership elements where teachers should be student-friendly, approachable, able to lead students, advise students, have the skills to educate and motivate students, and have the knowledge to guide students to excel both in academic and life. The importance of teacher leadership is again emphasised by Barth (2002), who explains that any innovation to improve school culture cannot succeed without the efforts of teachers and administrators. Therefore, in this study, four aspects of teacher leadership are being studied, which are the teacher leadership in the classroom, as a role model, in school leadership and promoting collaboration.

Behaviour is an act that can be evaluated, measured, observed directly or indirectly, and consciously or half-consciously. Behavior is the physical manifestation of any attitude based on specific values (Norsita \& Zainal, 2012). Teachers act as a primary mentor for the students to improve their academic performance in the school. They play a significant part in replacing the parent's role in schools by giving encouragement and blessing to the students. This role will enhance students' interest, understanding and facilitate their knowledge acceptance in the classroom. Moreover, students presume that teachers are an essential medium in delivering knowledge as they are a source of inspiration in motivating them to strive for success (Mohamad, Mazliza \& Jane (2012). Teachers also play a significant role as an agent in leading excellence by shaping the classroom climate through the relationship between teachers and students. Wan et al. (2009) define classroom climate as a learning environment that reflects the classroom 
atmosphere, teaching process, how the teachers treat them and teachers' expectations towards them. Therefore, teachers must display a positive attitude towards them and provide fair treatment to all students. This act will make a massive impact on their academic performance and achievement.

In order to produce quality teachers, the Ministry of Education Malaysia (MOE) had introduced the Malaysian Teacher Standard (SGM) in 2009. This document will act as guidelines to help teachers to identify what are the professional competencies that they need to achieve in their teaching and learning process. It also serves as a guidance and reference to the teachers, teacher's educators, agencies and teacher educational institution to produce high-quality teachers to lead education in schools. The three primary standards are the practice of teaching professionalism, knowledge and understanding, and teaching and learning skills.

\section{Student Motivation}

Motivation is a contributing factor to academic excellence. According to Meor and Nuremelia (2010) and Nik, Zamri and Kamarulzaman (2008), highly motivated learners will strive to achieve their goals, dreams and ambitions. Students who have a purpose organised study plans and make early preparation for their examination will likely influence their academic achievement in leading learning. According to Azizi, Boon and Kamaliah (2010), motivation is the intervention process that motivates the person to act, direct and pursue a behaviour.

The theory of self-efficacy has been widely used to understand gender differences in motivation and achievement pattern. Self-efficacy is closely related to academic achievement (Parisa, 2011). According to Low and Zahari (2012) and Wan (2014), motivation is the only factor that contributes to students' academic achievement. It defined as how a student perceives their own ability to complete the task successfully, to learn something or to perform behaviour at a given level. This self-efficacy influences students in the areas of effort, perseverance, responsibility, and achievement.

\section{Parental Commitment}

Commitment refers to the emotional feelings, ideas, philosophies, and values that are internalised by an individual while performing tasks. It also includes a collection of opinions and beliefs brought by members of the organisation (Zulkafli, 2008; George \& Jones, 1996; Mowday, Porter \& Steers, 1982). Parental involvement not only benefits students and parents, but it also affects teachers' and schools' commitment to the students (Hoover-Dempsey \& Sandler, 2005). According to Hendersen and Mapp (2002), many studies have found that when parents demonstrate a commitment to their children's education, students will achieve good results, pass the examination, go to school daily, have an excellent social and behavioural skills, be able to adapt well in school and successfully finished their study. 
Study of Azizi and Mohamad (2010) reveal that parents' commitment is a significant factor in achieving success in aborigines' school. A real engagement from the aborigine's parents will determine the excellence of these schools. There are four main focus areas in this study which are the provision of student education funds, the provision of a learning environment, communication with the children, and support and motivation to the children excellence. Parents can be leaders in leading learning through high expectations (Jeynes, 2005) and the provision of learning tools (Mohamad et al., 2009). A complete school supplies will motivate the student to attend school daily (Mohamad, Mazliza \& Jane, 2012; Mahyuddin and Ahmad, 2011). This situation also applied in their home; a complete learning needs at home can help students to be more motivated to study at home. According to Graves (2011), family involvement in student academic achievement defined as the influence of parents in changing students' behaviour beyond formal learning time.

\section{Methodology}

This research is an exploratory study. The respondents selected among the principals and teachers who serve in aborigines' schools. A total of nine principals participated in this study, eight $(88.9 \%)$ were male principals, and one (11.1\%) was female principals. This study also involved 113 teachers from nine schools. The selected teachers consisted of 61 (54.0\%) male teachers and 52 (46.0\%) female teachers. Data were collected using the School Level Environment (SLEQ) questionnaire (Fisher \& Fraser, 1990); the role of principals (Halinger \& Murphy, 1985), teacher leadership (NRGS, UPSI, 2015), teacher motivation and behaviour (Marzano et al., 1997), and parental commitment (Mowday et al., 1982). All questionnaires used a five-point scale. Data analysed using descriptive statistics.

\section{The Findings}

The findings of this study shown in Table 1. The perception of the principals and teachers compared to all the factors studied. Giving a more specific insight of the result, the principals has picked Roles of Principal with the highest mean $(M=4.61 ; S D=.317)$, followed by School Climate and Teacher Leadership factors $4.47(S D=.523$; $S D=.523)$, Student Motivation $(M=3.65 ; S D=$ $.534)$, and Parental Commitment ( $M=3.56$; $S D=.729)$. The least significant factor was Teacher Behaviour ( $M=3.53 ; S D=3.53$ ). These findings indicate that the climate or atmosphere in the school is safe and comfortable. However, the behaviour of teachers who teach aborigines students still needs more attention.

The summary for the teachers' perceptions analyses are as the following. Of all factors, the school climate and the role of the principals show the highest mean score of $M=4.32$ (SD respectively 0.414 and .425 , respectively), followed by Teacher Leadership factors $(M=4.26 ; S D=.585)$, Student Motivation ( $M=3.62 ; S D=.640)$, Teacher Behaviour $(M=3.34 ; S D=.509)$ and Parental Commitment $(M=3.33 ; S D=.688)$. Overall, teachers are also agreed that teacher behaviour and parent commitment need to be enhanced further. 
The findings also showed that both principals and teachers share the same level of perception in school climate sub factors. For all three-school climate sub factors, both the principals and teachers agreed that social sub factors documented the highest mean score followed by psychosocial sub factors and environment sub factors.

In the following analysis, a total of 11 principals' role sub factors studied. For this factor, the principals show higher perceptions level than the teacher. The principals perceived, setting the goals of the school deserve the highest priority, followed by fostering staff development, providing rewards for students, implementing and enforcing the latest academic standards and sub factors to support teaching activities. Teachers viewed that providing students with rewards is the most crucial sub factor followed by cultivating staff development, defining school goals, implementing and enforcing academic standards, and ultimately controlling and protecting teaching hours. The findings of this study indicate there is a similarity of perception between the principals and teachers, especially in staff development as well as in implementing and enforcing academic standards.

Table 1

Factors Defining Indigenous School Excellence from Principal's and Teacher's Perceptions

\begin{tabular}{lcccc}
\hline \multicolumn{1}{c}{ Factor } & Mean & $\begin{array}{c}\text { Standard } \\
\text { Deviation }\end{array}$ & Mean & $\begin{array}{c}\text { Standard } \\
\text { Deviation }\end{array}$ \\
\hline School Climate & &. $\mathbf{2 2 5}$ & $\mathbf{4 . 3 2}$ & .414 \\
Environment & 4.47 & .313 & 4.17 & .480 \\
Social & 4.67 & .261 & 4.41 & .416 \\
Psychosocial & 4.51 & .253 & 4.40 & .748 \\
Function of the Principal & 4.61 & .317 & $\mathbf{4 . 3 2}$ & .425 \\
Determining School Objectives & 4.86 & .253 & 4.38 & .469 \\
Clarifying School Objectives & 4.64 & .417 & 4.40 & .461 \\
Oversee and Assess Teachers' Teaching & 4.53 & .384 & 4.27 & .479 \\
Curriculum Coordination & 4.50 & .451 & 4.27 & .464 \\
Monitoring Student Academic Progress & 4.56 & .410 & 4.24 & .487 \\
Control and Protect Teaching Time & 4.50 & .415 & 4.14 & .519 \\
Provide Support for Teaching Activities & 4.44 & .583 & 4.18 & .547 \\
Providing Teacher Incentives & 4.61 & .333 & 4.35 & 1.083 \\
Cultivating Staff Development & 4.72 & .384 & 4.40 & .462 \\
Apply and Enforce Academic Standards & 4.67 & .415 & 4.32 & .483 \\
Providing Student Rewards & 4.69 & .349 & 4.54 & 1.547 \\
Teacher Leadership & 4.47 & .523 & 4.26 & .585 \\
Leadership in Classroom & 4.49 & .315 & 4.26 & .684 \\
Become an Example & 4.52 & .311 & 4.27 & 1.113 \\
Leader in School & 4.27 & .447 & 4.02 & .568 \\
\hline & & & & 1253 \\
\hline
\end{tabular}


INTERNATIONAL JOURNAL OF ACADEMIC RESEARCH IN BUSINESS AND SOCIAL SCIENCES

Vol. 9, No. 11, November, 2019, E-ISSN: 2222-6990 @ 2019 HRMARS

\begin{tabular}{lcccc}
\hline \multicolumn{1}{c}{ Factor } & Mean & $\begin{array}{c}\text { Standard } \\
\text { Deviation }\end{array}$ & Mean & $\begin{array}{c}\text { Standard } \\
\text { Deviation }\end{array}$ \\
\hline Encourage Cooperation & & .418 & 4.31 & .830 \\
Student Motivation & 3.65 & .534 & $\mathbf{3 . 6 2}$ & .640 \\
Efficacy & 3.96 & .397 & 3.84 & .582 \\
Motivation & 4.07 & .600 & 3.76 & .746 \\
Learning Style & 3.38 & .738 & 3.36 & .809 \\
Objective & 3.69 & .544 & 3.64 & .746 \\
Parents & 3.70 & .655 & 3.64 & .689 \\
Teacher Behaviour & 3.53 & 1.289 & 3.34 & .509 \\
Clarity & 4.07 & .671 & 3.25 & .605 \\
Passion & 3.83 & .471 & 3.20 & .615 \\
Interaction & 3.76 & .349 & 3.27 & .739 \\
Organisation & 4.25 & .334 & 3.73 & 1.103 \\
Attitude & 3.88 & .455 & 3.02 & .727 \\
Thinking & 3.93 & .489 & 3.36 & .590 \\
Speech & 3.58 & .292 & 3.41 & .569 \\
Relation & 4.31 & .422 & 3.68 & .456 \\
Parental Commitment & 3.56 & .729 & 3.33 & .688 \\
Provision of Student Education Fund & 3.69 & .742 & 3.49 & .669 \\
Providing a Learning Environment & 3.56 & .921 & 3.24 & .770 \\
Communication with Child & 3.42 & .809 & 3.34 & .670 \\
Child Excellence Support and Motivation & 3.56 & .811 & 3.26 & 1.119 \\
\hline
\end{tabular}

Focusing on Teacher Leadership factor, the principals show a higher level of perception than teachers. From the principals' view, the most crucial role as a teacher leader is to become an exemplar ( $M=4.52, S D=4.311)$ followed by being a classroom leader $(M=4.49 ; S D=.315)$, promoting collaboration $(M=4.47 ; S D=.418)$ and becoming a leader in schools $(M=4.27$, $\mathrm{SD}=.447)$. Whereas from the teacher's view, the main sub factor is promoting collaboration, followed by exemplars, becoming leaders in the classroom and eventually becoming leaders in the school.

For the students' motivation factor, the principals selected the Motivation sub factor as the main factor, while the teacher selected the student Self-efficacy sub factor as the main factor. Both respondents choose the Learning style sub factor as the last selected sub factor. For teacher Behaviour factor, the principals selected the Relationship sub factor as the primary choice, while the teachers chose the Organizational sub factor as their primary choice. The principals selected the Organizational sub factor as the second choice, while the teachers selected the Relationship sub factor as their second choice. The principals decided the Speech factor as the last sub factor, while the teachers selected the Attitude sub factor as the previous choice. For the Parents' commitment factor, the principals and the teachers chose the Provision of student education 
funds sub factor as the top choice. There was no similarity for all respondents in terms of parental commitment.

\section{Discussion and Conclusion}

This study provides evidence that the roles of principals are vital in establishing excellent in aborigines' schools. Many studies have found that the role of the principals is essential in improving student academic achievement (Mohd \& Aziz, 2014; Hamidah \& Norasibah, 2011; Waters, Marzano \& McNulty, 2003). In particular, the principals are a mentor to all members of his organisation (NorFoniza \& Mohd, 2013; Senge, 2006). In the teaching and learning process, principals play a major role in guiding teacher behaviour and also as a leader in this process (Hallinger \& Murphy, 1987; 1985). Principals also play a significant role in changing the ecology of schools and organisations (Abdul et al., 2014). They are also responsible for developing and achieving school goals (Abdul, Aziah \& Tang, 2008).

The findings of this study also indicate that the Teacher Leadership factor is essential to guide student learning. Teachers also play a crucial role in achieving effective school and academic excellence (Billingsley, 2007; Danielson, 2006; Little, 2003). Committed teachers will successfully create a learning environment that motivates students to succeed academically. Teacher behaviour can be enhanced further. According to Isaac and Fin (2013), an exemplary teacher is a teacher who practices goodness, have good behaviour and have high self-discipline. Moreover, to ensure the success of teaching and learning activities, teachers should be able to use effective teaching methods and techniques, that can influence students in improving their achievement (Katzenmeyer \& Moller, 2009; Greenlee, 2007; Muijs \& Harris, 2003). Therefore, to educate the aborigines pupils, teachers need to understand the student's needs and wants.

Based on the findings of this study, it suggested that principals and teachers should take the following action; maintain a pleasant social climate in schools, learn the culture of aborigines peoples to find an appropriate teaching and learning techniques that aligned with the existing culture, and teachers should serve as supporter and motivator to the students. The Ministry of Education also should consider ways to make the education system unequal for all groups. A specialise trained teachers for aborigines' schools may also be one of the ways to improve the native education system.

In conclusion, the school climate, the role of the principal, teacher leadership, teacher behaviour, student motivation, and parental commitment are all crucial factors in the education of a student in aborigine school, each factor intertwined with the other factor. Thus, the academic achievement of a student in a school will be achieved after all these factors are practised seriously at school. For example, a positive and productive school climate can foster integration and harmony among students. Friendly relationships within the school community will create better education. Productive school climate will create a stimulating learning environment and will help students achieve better academic achievement among students. It proposed that a 
INTERNATIONAL JOURNAL OF ACADEMIC RESEARCH IN BUSINESS AND SOCIAL SCIENCES

Vol. 9, No. 11, November, 2019, E-ISSN: 2222-6990 ㄷ 2019 HRMARS

comprehensive education development plan be developed specifically for the quality aborigine's pupils' education, taking into account all the factors derived from this study.

\section{Appreciation}

The writer's express gratitude on the funding of this grant from the Ministry of Education (FRGS/2/2013/SS109/UPSI/02/3) and Centre of Research and Innovation (Research Code: 20130180-107-02), Universiti Pendidikan Sultan Idris to conduct this research.

\section{References}

Abdul, G., Aziah, I., \& Tang, K.N. (2008). Kesan pincang laku kepimpinan pengetua terhadap guru. Pulau Pinang: Universiti Sains Malaysia.

Abdullah, S. Y., Abdul, R. M., Abdul, G. A. (2011). Guru sebagai pemimpin. Kuala Lumpur: PTS Professional Publishing Sdn.Bhd.

Ahmad, R. I. (2013). Kajian kes strategi kepimpinan guru besar cemerlang. Tesis Sarjana, Universiti Teknologi Malaysia.

Azizi, Y., \& Mohamad, H. O. (2010). Masalah Rakan Sebaya. Fakulti Pendidikan, Universiti Teknologi Malaysia.

Azizi, Y., Boon, Y., \& Kamaliah, N. (2010). Hubungan antara konsep kendiri, motivasi dan gaya keibubapaan dengan pencapaian. Universiti Teknologi Malaysia, Skudai Johor, Malaysia. Retrieved from http://eprints.utm.my/2332/

Barth, R. S. (2002). Improving schools from within. San Francisco: Jossey Bass.

Billingsley, B. S. (2007). Recognizing and supporting the critical roles of teachers in special education leadership. Exceptionality, 15, 163-176.

Boon, Y. (2005). Kecerdasan emosi dan hubungannya dengan pencapaian akademik dan tingkah laku pelajar. Thesis, Universiti Teknologi Malaysia.

Centre for Curricuum Development (Pusat Perkembangan Kurikulum). (1981). Kurikulum Baru Sekolah Rendah: Matlamat, rasional, bidang pelajaran dan strategi pengajaran dan pembelajaran. Kuala Lumpur: Pusat Perkembangan Kurikulum.

Cibulka, J., Coursey, S., Nakayaman, M., Price, J. \& Stewart, S. (2003). Schools as learning organizations: A review of the literature. National College for School Leadership retrieved from http://www.ncsl.org.uk/ncl.

DeBevoise, W. (1984). Synthesis of research on the principal as an instructional leader. Educational Leadership, 41(5), 15-20.

Danielson, C. (2006). Teacher leadership that strengthens professional practice. Alexandria, VA: Association for Supervision and Curriculum Development.

Fisher, D., \& Fraser, B. (1990) School-level Environmental Questionnaire. Retrieved from http://www.nzcer.org.nz/nzcerpress/set/articles/school-level-environment-questionnairesleq

George. J. M. \& Jones, G. R. (1996). Understanding and managing organizational behavior. New York: Addison-Wesley Publishing Co. Inc. 
Grave, B. S. (2011). The effect of student time allocation on academic achievement. Education Economics, 19, 291-310. DOI:10.1080/09645292.2011.585794

Greenlee, B. J. (2007). Building teacher leadership capacity through educational leadership programs. Journal of Research for Educational Leaders, 4(1), 44-74.

Hallinger, P., \& Murphy, J. (1985). Characteristics of highly effective elementary school reading programs. Educational Leadership, 45(5), 39-42.

Hallinger, P. \& Murphy, J. (1987). Assessing the instructional leadership behavior of principals. Elementary School Journal, 23, 34-45.

Halpin, A., \& Croft, D. (1963). The organizational climate of schools. Chicago: The University of Chicago.

Hamidah, Y., \& Norasibah, A. J. (2011). Kesan tugas pengetua kepada pencapaian pelajar. Academic Development Higher Education Conference 2011.

Henderson, A. T., \& Mapp, K. L. (2002). A new wave of evidence: The impact of family, school, community connections on student achievement. Austin, TX: Southwest Educational Development Laboratory.

Hendri, B. (2012). Hubungan Gaya Mengajar Guru Terhadap Motivasi Belajar Matematika Pada Siswa Madrasah Ibtidaiyah Ma'arif Pulutan Salatiga. Tesis Sarjana Pendidikan Guru Madrasah Ibtidaiyah.

Hoover-Dempsey, K. V., \& Sandler, H. M. (2005). The social context of parental involvement: A path to enhanced achievement. Final performance report for the Office of Educational Research and Improvement (Grant No. R305T010673). Presented to Project Monitor, Institute of Education Sciences, U.S.Department of Education.

Hoy, W. K. \& Miskel, C. G. (2008). Educational administration: Theory, research and practice. America: McGraw Hill Companies, Inc.

Ishak, M. S. (2006). Kepimpinan dan hubungan interpersonal dalam komunikasi. Kuala Lumpur: Universiti Teknologi Malaysia.

Jeynes, W. H. (2005). Parental involvement and student achievement: A meta-analysis Harvard Family Research Project. Retrieved from http://hfrp.org/publications-resources/browseour-publications/parental-involvement-and-student-achievement-a-meta-analysis

Jeynes, W. H. (2007). The relationship between parental involvement and urban secondary school student academic achievement: A meta-analysis. Urban Education, 42(1), 82-110.

Kamarulzaman, K., \& Osman, J. (2008). Educational policy and opportunities of Orang Asli: A study in indigenous people in Malaysia. The Journal of Human Resource and Adult Learning, 4(1), 86-97.

Katzenmeyer, M., \& Moller, G. (2009). Awakening the sleeping giant: Helping teachers develop as leaders (3rd ed.). Thousand Oaks, CA: Corwin Press.

Koth, C. W., Bardshaw, C. P., \& Leaf, P. J. (2008). A multilevel study of predictors of student perceptions of school climate: The effect of classroom-level factors. Journal of Educational Psychology, 100, 96-104.doi:10.1037/0022-0663.100.1.96 
INTERNATIONAL JOURNAL OF ACADEMIC RESEARCH IN BUSINESS AND SOCIAL SCIENCES

Vol. 9, No. 11, November, 2019, E-ISSN: 2222-6990 @ 2019 HRMARS

Little, J. W. (2003). Constructions of teacher leadership in three periods of policy and reform activism. School Leadership and Management, 23, 201-419. DOI: 10.1080/1363243032000150944

Low, S. F., \& Zahari, I. (2012). A priori model of students' academic achievement: the effect of gender as a moderator. Procedia - Social and Behavioral Science, 65, 1092-1100.

MacBeath, J. (2005). Leadership as distributed: A matter of practice. School Leadership and Management, 25(4), 349-66. https://doi.org/10.1080/13634230500197165

Mahmud, Z., Amat, S., and Yaacob, M. (2008). Educational issues of Orang Asli Students in Malaysia. The International Journal of Diversity in Organisations, Communities and Nations, 8(6), 121-128.

Mahyuddin, A., \& Ahmad, M. A. (2011). Faktor perbezaan pencapaian akademik pelajar lepasan diploma dan matrikulasi. Universiti Teknologi Malaysia. Retrieved from eprints.utm.my/11813/

Marzano, R. J., Pickering, D. J., Arredondo, D. E., Blackburn, G. J., Brandt, R. S., \& Moffett, C.A. (1997). Dimension of learning trainers' manual. http://citeseerx.ist.psu.edu/viewdoc/download.

Meor, I. K., \& Nuremelia, M. R. (2010). Kaitan faktor penyumbang dengan kecemerlangan akademik pelajar asrama harian. Universiti Teknologi Malaysia.

Ministry of Education Malaysia. (2018). Malaysia Educational Blueprint (2013-2015). Annual Report.

Misnah, R., Hamidah, Y., \& Marinah, A. (2015). Leading learning: A grounded theory perspective of Orang Asli parental involvement and engagement. $2^{\text {nd }}$ Global Conference on Business and Social Science. Bali, Indonesia.

Mohamad, J. S., Che, N. H., Ismael, H., \& Amir, H. D. (2009). Status sosio ekonomi dan komitmen ibu bapa terhadap pencapaian pelajar dalam penilaian menengah rendah, Malaysia. Sultan Hassanal Bolkiah Institute of Education, Universiti Brunei Darussalam.

Mohamad, J. S., Mazliza, K., \& Jane, F. H. (2012). Kajian terhadap faktor-faktor mempengaruhi pencapaian pelajar dalam penilaian menengah rendah di Sabah. Labuan International Conference Educational Research, Financial Park Complex Wilayah Persetuan Labuan.

Mohd, Y. I., \& Aziz, A. (2014). Model kepemimpinan pengajaran pengetua dan kompetensi pengajaran guru. Jurnal Kurikulum \& Pengajaran Asia Pasifik, 2(1), 12-25.

Moskal, B. M., \& Bath, B. B. (2001). A Response to the NCTM Standards: Confidence and Competence Project.

Mowday, R., Porter, L., \& Steers, R. (1982). Employee-organization linkages: The psychology of commitment, absenteeism, and turnover. New York: Academic Press.

Muhamad, A. I., Wan, W. S., Sarah, W. M. H., \& Siti, F. A. A. (2016). Pengaruh iklim organisasi terhadap tingkah laku kewarganegaraan organisasi dalam kalangan penjawat awam. Journal of Social Sciences and Humanities, 11(2), 1-16.

Muijs, D., \& Harris, A. (2003). Teacher leadership - Improvement through empowerment? An overview of the literature. Educational Management \& Administration, 31(4), 437-448. 
Nicholas, C. (2006). The state of Orang Asli education and its root problems. An article prepared in July 2006 for the Human Rights Commission of Malaysia (SUHAKAM). Retrieved from, http://www.coac.org.my/codenavia/portals/ coacv2/images /articles /OA\%20 Education.pdf.

Nik, M. R. N. Y., Zamri, M., \& Kamarulzaman, A. G. (2008). Motivasi pembelajaran kemahiran mendengar bahasa arab dan hubungannya dengan pencapaian pelajar. Jurnal Pendidikan, 33, 3-18.

NorFoniza, M., \& Mohd, I. M. H. (2013). Pengetua pemacu organisasi pembelajaran. Seminar Pengurusan dan Kepimpinan Pendidikan Kali ke-19. Institut Aminuddin Baki, Kuala Lumpur.

Norreza, M. T. (2011). Peranan guru pembimbing: Bimbingan terhadap guru pelatih semasa latihan mengajar. Thesis, Universiti Tun Hussein Onn Malaysia.

Norsita, A., \& Zainal, M. (2012). Tinjauan awal interaksi guru-kanak-kanak dalam pemupukan pemikiran kreatif kanak-kanak. Proceeding of the Social Sciences Research ICSSR 2014 (eISBN 978-967-11768-7-0). Kota Kinabalu, Sabah, Malaysia.

Norwaliza, A. W., Ramlee, M. \& Abdul, R. A. (2016). The Roles of Administrators in Aboriginal Schools: A Case Study in a Malaysian State. International Journal of Social Science and Humanity, 6(5), 370-374.

Ragbir, K. J. S. (2010). Panduan ilmu pendidikan untuk DPLI psikologi. Kuala Lumpur: Kumpulan Budiman Sdn Bhd.

Parisa, R. (2011). The relationship between self-esteem, achievement goals and academic achievement among the primary school students. Procedia-Social and Behavioral Sciences 29, 803-808.

Salhah, A., \& Ainon, M. (2007). Guru sebagai mentor. Kuala Lumpur: PTS Publications.

Scholtes, P. R. (2005). The leader's handbook. New York: McGraw-Hill.

Senge, P. M. (2006) The Fifth Discipline: The Art and Practice of the Learning Organization. Doubleday (A Division of Random House), New York, 7.

Sergiovanni, T. (1987). The principalship: A reflective practice perspective. Boston, NY: Allyn and Bacon.

Sergiovanni, T. (1992). Moral Leadership. San Francisco: Jossey Bass.

Sharifah, M. N., Samsilah, R., Aminuddin, M., Kamaruddin, A. H., Mohamad, A. M. A., \& Jaimah, A. M. (2011). Dropout prevention initiatives for Malaysian indigenous Orang Asli children. The International Journal on School Disaffection, 8(1), 42-56.

Shippen, M. E., \& Shippen, S. J. (2004). Seven characteristics of effective leaders. Classroom Leadership, 7(8). Retrieved from a

Southworth, G. (2002). Instructional leadership in schools: Reflections and empirical evidence. School Leadership and Management, 22(1), 73-92.

SUHAKAM. (Suruhanjaya Hak Asasi Manusia Malaysia) (2010). Laporan status hak pendidikan kanak-kanak orang Asli. Kuala Lumpur: SUHAKAM.

Szabo, M. A., \& Lambert, L. (2002). The preparation of new constructivist leaders. In Linda Lambert et al. (Ed), The constructivist leader (2 ${ }^{\text {nd }} E d .$, pp. 204-238) New York: Teachers College Press. 
Tarmiji, M., Fujimaki, M., \& Norhasimah, I. (2013). Orang Asli in Peninsular Malaysia: Population, Spatial Distribution and Socio-Economic Condition. Journal of Ritsumeikan Social Science and Humanity, 6, 75-115.

UNICEF. (2011). News release: Malaysia's MDG 2010 report underlines growing inequalities despite national progress. Retrieved from http://www.unicef.org/malaysia/media_news11malaysia-mdg-2010-report-underlines-gaps-and-disparities. Html

Wan, H. S. W. M. (2014). Pengaruh budaya sekolah, strategi pembelajaran dan efikasi kendiri terhadap pencapaian akademik pelajar. PhD Thesis, Universiti Pendidikan Sultan Idris.

Wan, Z. W. A., Sharifah, M. N., Siti, S. S., Othman, M., Kamariah, A. B., Arshad, A. S., Ramlah, H., Rohai, A. T., Rasid, J., \& Hayat, M. (2009). Persepsi pelajar berisiko terhadap iklim pembelajaran. Jurnal Pendidikan Malaysia 34(1), 17-36.

Waters, T., Marzano, R. J., \& McNulty, B. (2003). Balanced leadership: What 30 years of research tells us about the effect of leadership on student achievement. McREL (Midcontinent Research for Education and Learning).

Zulkafli, K. (2008). Penglibatan guru dalam membuat keputusan, sokongan organisasi dan komitmen kerja. Thesis, Universiti Sains Malaysia. 